\title{
Body Weight Fasting Status
}

National Cancer Institute

\section{Source}

National Cancer Institute. Body Weight Fasting Status. NCI Thesaurus. Code C119784.

An indication or description of whether a body weight measurement was obtained from a subject that has abstained from food and possibly water for the prescribed amount of time. 